\title{
Beyond Existentialism: Kierkegaard on the Human Relationship with the God Who is Wholly Other
}

\author{
Andrew B. Torrance
}

\begin{abstract}
Recent scholarship argues that, for Kierkegaard, God's absolute alterity is a consequence of $\sin$ that is overcome by the redemptive activity of Jesus Christ. On such a reading, the work of Christ delivers individuals to lives of faith that are not infinitely qualitatively different from God. This fails to recognise that the absolute otherness of God is overcome not simply by the redemptive work of Christ but in and through the person of Christ. The failure to grasp this has tied Kierkegaard to an anthropocentric theology that prioritises Christ's contribution to existential human development. This essay challenges this perception by establishing Kierkegaard's emphasis that God would remain infinitely removed from humanity were it not for the continuing mediation of Jesus Christ.
\end{abstract}

In his recent work, Kierkegaard and the Theology of the Nineteenth Century, George Pattison contends that '[i]f we are to draw a parallel [between Kierkegaard] and the major Protestant theologians of the twentieth century, it is not to Barth and his denial of any point of contact between divine and human that we should look but to Bultmann and his insistence that revelation can only be meaningful if the human being to whom it is revealed is capable of understanding what is revealed to him $[\mathrm{sic}] .{ }^{1}$ When we read Kierkegaard's works, particularly his early works, there is much to be said for this claim. Kierkegaard does indeed engage with the question of what it means to exist as a Christian by reflecting meaningfully, in the light of one's existence, on the texts of Scripture. At the same time, however, there is another dimension to Kierkegaard's thought that cannot be ignored - one that achieved prominence in his later works or "second" authorship. For Kierkegaard, there is an infinite qualitative difference between the divine and the human that always remains - that is, apart from the God-human unity that is established in the incarnate person of Jesus Christ.

\footnotetext{
${ }^{1}$ George Pattison, Kierkegaard and the Theology of the Nineteenth Century: The Paradox and the Point of Contact (Oxford: Oxford University Press, 2012), pp. 89-90; see also George Pattison, Kierkegaard and the Quest for Unambiguous Life (Oxford: Oxford University Press, 2013), pp. 115-6; George Pattison, The Philosophy of Kierkegaard (Montreal \& Kingston: McGill-Queen's University Press, 2005), pp. 149-50.
} 
In this article, I seek to show how Kierkegaard's emphasis on the infinite qualitative difference serves to direct our attention to the reality of the God-human (Gud-Mennesket), that is, to the 'mediator' 'who leads us to God.' ${ }^{2}$ By so doing, I consider how Kierkegaard's appreciation of the absolute alterity of God serves to challenge the more humanistic visions of Christianity that exalt human ideas of God over and above the personal reality of God who encounters us as Immanuel, God with us.

Integral to my argument is the contention that, in Kierkegaard's thought, the infinite qualitative difference does not simply dissolve when a person is reconciled into a faithful relationship with God. Indeed, Kierkegaard testifies to an absolute otherness of God that finds no point of contact with humanity apart from that "individual" who is Jesus Christ. This absolute otherness means that the full reality and, indeed, truth of the divine subject never becomes an object of human understanding. God always remains a personal subject who is known in and through an inter-personal relationship with the God who is with us and for us as Jesus Christ. I then consider how this relates to Kierkegaard's (or rather his pseudonym Johannes Climacus') (in)famous statement "subjectivity is truth". ${ }^{3}$ Finally, I conclude with a brief consideration of the low pneumatology apparent in Kierkegaard's account of humanity's relation to God, and ask why the Holy Spirit did not play a greater role in Kierkegaard's account of this relationship.

\section{Questioning Kierkegaard's christocentricity}

\section{Hirsch and Barth on Kierkegaard's anthropocentric theology}

Ever since the early days of Kierkegaard scholarship, there has been a fascination with his account of the existential development of the Christian in ways that have sidelined his appreciation of the role of God in this. This is particularly evident in the work of the German

\footnotetext{
${ }^{2}$ Søren Kierkegaard, Søren Kierkegaard Skrifter vol. 25, ed. Niels Jørgen Cappelørn, Joakim Garff, Kette Knudsen, Johnny Kondrup, Alastair McKinnon and Finn Hauberg Mortensen (Copenhagen: Gads Forlag, $1997-$ 2013) (hereafter SKS), pp. 140-2, NB27:23 / Søren Kierkegaard, Journals and Papers, vol. 2, ed. \& trans. Howard V. and Edna H. Hong (Bloomington: Indiana University Press, 1967-78) (hereafter JP), 1432.

${ }^{3}$ In this essay, I respect Kierkegaard's wish 'that anyone who wants to quote something from the pseudonyms will not attribute that quotation to me.' (Søren Kierkegaard, Søren Kierkegaard Papirer, vols. I-XVI (second expanded edition), ed. Niels Thulstrup, vols. XII to XIII supplementary volumes, ed. Niels Thulstrup (Copenhagen: Gylendal, 1968-78) (hereafter Pap.), X-6 B 145 / JP 6, 6786). Two of the key pseudonyms with which I shall engage are Johannes Climacus who describes himself as an 'outsider' to the Christian faith and Anti-Climacus, who is described as an extraordinary Christian. (SKS 7, p. 26 / Søren Kierkegaard, Concluding Unscientific Postscript to Philosophical Fragments, ed. \& trans. Howard V. and Edna H. Hong (Princeton: Princeton University Press, 1992) (hereafter CUP), p. 16; Pap. X-6 B 48 / JP 6, 6349).
} 
scholar Emanuel Hirsch, who, from the 1920s onward, became the leading German expert on Kierkegaard. This led to what Heiko Schulz describes as the 'Germanisation' (Verdeutschung) of Kierkegaard. ${ }^{4}$ Driven by his strong Nationalist and, post 1933, National Socialist convictions, Hirsch was instrumental in the German enculturation of Kierkegaard a move that was coloured by Hirsch's idealist and Romantic vision of Kierkegaard's theology.

In 1921, Hirsch's path crossed with Karl Barth when they started teaching together at Göttingen - Hirsch in church history and Barth in Reformed theology. Right from the start, Barth found himself impressed by Hirsch, a man with 'a profound knowledge of Luther and Fichte, an effete scholar of the kind to be found in books, German nationalist to his very bones, but a notable phenomenon'.5 Although he regarded Hirsch as 'learned and perspicacious', this did not hold him back from locking horns with him. ${ }^{6}$ In a well-known letter to Eduard Thurneysen on February 26, 1922, ${ }^{7}$ in which Barth reports Hirsch's theses and his own antitheses, Barth critiques his account of the Christian life as defined by selftransformation, guided by a reading of Scripture and grounded in surrender to God. For Hirsch, we understand our relationship with God by looking to how the exemplary figures of Scripture related to God. By this means, we construct an idea of the Christian life that we can then apply to our own existence. Such an account was antithetical to Barth, who sought to stress the importance of the reality (as opposed to ideality) of God in his relationship with us and action toward us in and through Christ. For Barth, the Christian life is life in Christ for which God creates us and into which God reconciles us - 'under God and in accord with God. ${ }^{8}$ What we see in Hirsch's account (as described by Barth) is the type of account that came to be associated with Kierkegaard in the first half of the twentieth century. Unfortunately, as Lee Barrett points out, when Barth differentiates himself from Hirsch's

\footnotetext{
${ }^{4}$ Heiko Schulz, 'Die theologische Rezeption Kierkegaards in Deutschland und Dänemark: Notizen zu einer historischen Typologie' in Kierkegaard Studies Yearbook 1999, ed. N.J. Cappelørn and H. Deuser (Berlin: Walter de Gruyter, 1999), p. 229. (Quoted and translated by Marcia Morgan in 'Adorno's Reception of Kierkegaard: 1929-1933' in Søren Kierkegaard Newsletter 46 (Northfield: Howard V. and Edna H. Hong Library, Sept. 2003), www.stolaf.edu/collections/kierkegaard/newsletters/Newsletter46.pdf, (accessed September 2012), p. 9).

${ }^{5}$ Written in a letter to W. Spoendlin, 21 December, 1921, quoted in Eberhard Busch, Karl Barth: His life and Autobiographical Texts, trans. John Bowden (Philadelphia: Fortress Press, 1976), p. 134.

${ }^{6}$ Karl Barth, Church Dogmatics IV/3, ed. G.W. Bromiley and T.F. Torrance (Edinburgh: T\&T Clark, 1962), p. 20.

${ }^{7}$ Karl Barth to Eduard Thurneysen, Revolutionary Theology in the Making: Barth-Thurneysen Correspondence, 1914-1925, trans. James Smart (Richmond: Westminster John Knox Press, 1964), pp. 82-8.

${ }^{8}$ Barth to Thurneysen, Revolutionary Theology in the Making, p. 83.
} 
position here, there is a sense in which he "was implicitly differentiating himself from what he took to be aspects of Kierkegaard's theological sensibility. ${ }^{9}$

So what is wrong with Hirsch's Kierkegaard? The Kierkegaard of Hirsch is very much an idealist and humanist Kierkegaard - a Kierkegaard who neglects the reality of the God of grace. As Matthias Wilke remarks, 'Hirsch reads Kierkegaard as a Christian thinker who belongs to the "idealist-romantic type in its superlative form." 10 This reading of Kierkegaard was undoubtedly influenced by Hirsch's disregard for the 'turn' (in Concluding Unscientific Postscript $)^{11}$ that Kierkegaard took to stress the decisiveness of the real God, revealed in Jesus Christ, for the Christian faith - an emphasis that is prevalent in his later religious authorship. ${ }^{12}$ Hirsch, like so many other Kierkegaard scholars - and second-hand followers of these scholars - did not take this turn seriously enough. It was this that led Barth to associate Hirsch's tendency to concentrate theology on anthropology with the 'Kierkegaard renaissance' of the $1920 \mathrm{~s}^{13}$

In light of this, Barth felt that Kierkegaard's existentialism needed to be tempered by a stronger appreciation of the reality of God's grace in order to avoid focusing on our sinful existences - and thereby becoming consumed by a 'sad pleasure or pleasurable sadness' and 'a seriousness that never allows [us]... to be really serious, a smile that can never be

\footnotetext{
${ }^{9}$ Lee C. Barrett, 'Karl Barth: The Dialectic of Attraction and Repulsion' in Jon Stewart, ed., Kierkegaard's Influence on Theology - Tome I: German Protestant Theology (Farnham: Ashgate, 2012), p. 15.

${ }^{10}$ Matthias Wilke, 'Emanuel Hirsch: A German Dialogue with "Saint Søren' in Kierkegaard's Influence on Theology - Tome I, p. 173; quoting Hirsch, Geschichte der neuern evangelischen Theologie im Zusammenhang mit den allgemeinen Bewegungen des europäischen Denkens vol. 5 (Gütersloh: Bertelsmann, 1949-54), p. 468. Wilke also notes here that Hirsch 'sees a direct connection between Kierkegaard and the Pietism of Herrnhuter, German Romanticism, Schleiermacher, and German idealism'.

${ }^{11}$ For Kierkegaard, Concluding Unscientific Postscript 'constitutes the turning point in my entire work as an author, inasmuch as it poses the issue: becoming a Christian.' That is, we find a turn to focus on what it means to be human before the reality of God. And at the centre of this turn is the one whom Climacus calls the "god in human form" or the "god in time". (SKS 16, p. 44 / Søren Kierkegaard, The Point of View for My Work as an Author, ed. \& trans. Howard V. and Edna H. Hong (Princeton: Princeton University Press, 1998) (hereafter PV), p. 63).

${ }^{12}$ See Heiko Schulz, 'Germany and Austria: A Modest Head Start' in Kierkegaard's International Reception Tome I: Northern and Western Europe, ed. Jon Stewart (Farnham: Ashgate, 2009), pp. 345-6. I should add that Hirsch did not totally disregard Kierkegaard's religious writings but did not distinguish them clearly enough from Kierkegaard's esthetic writings. In appreciation of Kierkegaard's (or Anti-Climacus') religious writing, Hirsch writes, 'The Sickness unto Death and Practice in Christianity, his two masterpieces as a Christian writer, as well as The Point of View, have greater prospect of being placed among the imperishable writings of the Christian Church than any other Christian-religious or Christian-theological productions of the nineteenth century.' (Emanuel Hirsch, Kierkegaard-Studien I, (Gütersloh: 1933; (reproduced) Vaduz: Topos Verlag, 1978), p. 229; quoted in the editors' 'Introduction' to Søren Kierkegaard, Practice in Christianity, ed. \& trans. Howard V. and Edna H. Hong (Princeton: Princeton University Press, 1991) (hereafter PC), pp. xviii-xix).

${ }^{13}$ Karl Barth, Ethics, ed. Dietrich Braun, trans. G.W. Bromiley (Edinburgh: T\&T Clark, 1981), p. 8; see also 17. It is highly likely that Barth will have had Hirsch in mind when he contends that 'the theologia naturalis vulgaris' is a 'depressing result [that] could be achieved even via Kierkegaard.' (Karl Barth, 'No!' in Barth and Brunner, Natural Theology, trans. Peter Fraenkel (London: Centenary Press, 1946), p. 121).
} 
laughter. ${ }^{, 14}$ According to Barth, too much Kierkegaard leaves us with a bittersweet perception of the gospel. Consequently, Barth recommended that Christian thinkers would benefit from attending 'schools other than Kierkegaard's'. ${ }^{15}$ The problem, however, with Barth's reading of Kierkegaard is that he failed to appreciate the more theological Kierkegaard who, as we shall see, really does seek to put the God revealed in Christ at the centre of the Christian faith. It is this failure that led Barth to ask whether Kierkegaard 'had not attacked but rather fortified' an anthropocentric, pietistic Christianity. ${ }^{16}$

\section{Disputing the absolute alterity of God}

Fifty years on and contemporary scholarship continues to associate Kierkegaard with a primarily anthropocentric vision of the Christian faith. This association derives from a failure to appreciate the absolute extent of God's otherness from human beings - alongside the understanding that the absolute difference between humanity and God is simply a consequence of sin. For example, in Jacob Howland's recent study of Kierkegaard, he contends that when a person repents and is reborn into the Christian life, she is no longer absolutely different from God, because the absolute difference is the consequence of the condition of untruth that sin produces. ${ }^{17}$ Merold Westphal also asserts that, for Kierkegaard, 'apart from sin God is not Wholly Other.' ${ }^{18}$ And this statement of Westphal's has recently been acknowledged by Simon Podmore who contends 'that Kierkegaard's vision of the relation between self and God is not reducible to a philosophy of alterity; but is rather conveyed via a theology of the "infinite qualitative difference" that is ultimately expressed through the mysterium of the impossible possibility of the forgiveness of sins. ${ }^{, 19}$ There is certainly an element of truth to these three interpretations. The problem, however, is that they interpret Kierkegaard's account of reconciliation by focusing exclusively on the forgiveness and conversion of human existence that takes place by means of Christ's atonement. This way of interpreting the grounds of union with God disregards Kierkegaard's understanding that

\footnotetext{
${ }^{14}$ Karl Barth, 'Kierkegaard and the Theologians', in Fragments Grave and Gay, trans. Martin Rumscheidt (London: Fontana, 1971), pp. 102-3.

${ }^{15}$ Barth, 'Kierkegaard and the Theologians', p. 104.

${ }^{16}$ Karl Barth, 'A Thank You and a Bow - Kierkegaard's Reveille' in Fragments Grave and Gay, p. 100.

${ }_{17}^{17}$ Jacob Howland, Kierkegaard and Socrates (Cambridge: Cambridge University Press, 2006), p. 203.

18 Merold Westphal, Overcoming Onto-Theology: Toward a Postmodern Christian Faith (Charlottesville: University Press of Virginia, 1998), p. 246.

${ }^{19}$ Simon Podmore, 'The Holy and the Wholly Other: Kierkegaard on the Alterity of God' in The Heythrop Journal, LIII (2012), p. 14.
} 
the absolute otherness of God is not simply due to the human individual's sinful mode of existence.

When one reads through Kierkegaard's writings, it is not difficult to see why such an interpretation of his theology of reconciliation might arise. Kierkegaard's pseudonym, Johannes Climacus, for example, recognises an underlying connection between God and the human insofar as the human arises out of God's being in action (God's acts of creation and preservation). ${ }^{20}$ Still further, he contends that this essential correspondence between God and human beings is distorted by $\sin$ - sin that he associates with the absolute difference between God and human beings. Yet, as we shall see, this does not lead Kierkegaard to suggest that reconciliation achieves unity between humanity and God - unless we are referring to the unity that is created in the individual person of Christ. While Howland, Westphal and Podmore do not claim that reconciliation achieves this kind of unity, this could easily be read from their arguments. This is because they fail to reflect Kierkegaard's insistence that an 'infinite qualitative difference' between the eternal God and contingent human beings 'always remains'. ${ }^{21}$

This danger is avoided with a more Christological reading of Kierkegaard: by recognising that, for Kierkegaard, it is primarily the person of Christ who reconciles us into a life of faithful relationship with God in which the infinite qualitative difference does not function as an alienating difference. It is not, therefore, primarily 'faith which reconciles humanity with God', as Podmore suggests - faith is merely a possibility that is enabled by Christ's reconciliation. ${ }^{22}$ In short, for Kierkegaard, God reconciles the world to himself in the person of Jesus Christ and not in the faith of the individual human. ${ }^{23}$ What needs to be stressed here is that any correspondence with God that is experienced in the life of faith is only made possible in and through the God-human, in whom there is reconciliation from the sin that totally alienates us from God. This is made possible because the incarnation creates a unity between God and an individual human being that has no reality until God became human in Christ and continues to have no reality outside that individual.

\footnotetext{
${ }^{20}$ Climacus writes, "if the god is to be absolutely different from a human being, this can have its basis not in that which man owes to the god (for to that extent they are akin) but in that which he owes to himself or in that which he himself has committed." (SKS 4, p. 252 / Søren Kierkegaard, Philosophical Fragments, ed. \& trans. Howard V. and Edna H. Hong (Princeton: Princeton University Press, 1985) (hereafter PF), pp. 46-7).

${ }^{21} 21$. SKS 20, p. 74, NB88 / Søren Kierkegaard, Kierkegaard's Journals and Notebooks vol.4, ed. Niels Jørgen Cappelørn, Alastair Hannay, David Kangas, Bruce Kirmmse, George Pattison, Vanessa Rumble, and K. Brian Söderquist (Princeton and Oxford: Princeton University Press, 2007-still in progress) (hereafter $K J N$ ), p. 73; Pap. VII-2 B235 / JP 3, 3087; SKS 21, p. 286, NB10:57 / KJN 5, p. 298.

${ }_{22}$ Podmore, 'The Holy and the Wholly Other', p. 14 (emphasis original).

${ }^{23} S K S$ 18, pp. 138-9, HH:25 / KJN 2, pp. 129-30.
} 


\section{Uniting the infinitely qualitatively different}

\section{Union in Jesus Christ}

To understand the basis for the Christian's relationship with God in Kierkegaard's theology, we need to turn to the one in whom there is unity between God and humanity. The critical point that Howland, Westphal and Podmore neglect is that the union between God and a human being, for Kierkegaard, is only located in the person of the God-human. Therefore, while there is a union between the full humanity of Jesus Christ and the humanity of every other human being, the atonement does not make possible a situation in which God (as he is in himself) stops being wholly other from humanity. Christ does not vanquish the infinite qualitative difference between God and human beings altogether; Christ's redemptive activity does not somehow pass on a God-human union to other individuals. In Kierkegaard's theology of reconciliation, God creates a real yet mediated kinship between human beings and God, as beings who are infinitely qualitatively different from one another but who are also fully united in Christ. ${ }^{24}$

What does this mean? It means that the atonement does not simply enable a redeemed state of human existence in which persons can know God by way of their own independent reflection, imagination and reason. The faith that the Christian receives does not enable her to possess a union with God in and through her own mind - a union that would enable her to summon up God by means of her own cognitive powers. In short, the work of Jesus Christ is not a means to a renewed unity between God and humanity. As Kierkegaard's pseudonym Anti-Climacus writes contra Hegel, '[t] he God-man is not the union [Eenhed] of God and man - such terminology is a profound optical illusion. The God-man is the unity of God and an individual human being. ${ }^{25}$ For Kierkegaard, Christ lives for us as the one in whom God unites himself with an individual human being, and through whom all other human beings can be reconciled with God. Salvation is only in and through Christ; the eternal truth of God is only communicated to humanity in and through the person of Christ rather than because of the work of Christ. 'Since he [Christ] is the Truth, you do not find out from him what Truth is

\footnotetext{
${ }^{24}$ See $S K S$ 21, p. 235, NB9:59 / KJN 5, pp. 244-5; SKS 23, pp. 236-7, NB17:92 / JP 3, 3646; SKS, 20, pp. 2523, NB:3:16 / KJN 3, p. 116; SKS 11, pp. 225-36 / Søren Kierkegaard, The Sickness unto Death, ed. \& trans. Howard V. and Edna H. Hong (Princeton: Princeton University Press, 1980), pp. 113-24; SKS 12, pp. 144-5 / $P C$, pp. 139-40.

${ }^{25} S K S$ 12, p. 94 / PC, p. 82 (emphasis mine).
} 
and now are left to yourself, but you remain in the Truth only by remaining in him' ${ }^{26}$ It is crucial to recognise here that, for Kierkegaard, the only point of contact between the divine subject and an individual human subject is found in Christ. While Howland, Westphal and Podmore do not deny this, they represent a body of scholarship that, due to lack of a more Christological focus, fails to articulate the decisive significance of this for Kierkegaard's thought.

There remains, however, a limit to Kierkegaard's Christological focus here. Kierkegaard does not suggest that the God-human unity achieved in the objectivity of the incarnation implies, in and of itself, the conversion of humanity to God. No one is born or automatically remains a Christian simply by virtue of the objective fact of Christ's life, death and resurrection, that is, without her subjective existence becoming transformed in and through an active relationship with God in history. To become a Christian disciple, for Kierkegaard, a person must be given the condition for learning the truth, and she must be given it at a particular moment in time from the one who is both god and human. ${ }^{27}$ Consequently, the Lutheran Kierkegaard would have been highly resistant to the Reformed H.F. Kohlbrügge's famous claim that 'he was converted on Golgotha' - a statement made famous by Barth. ${ }^{28}$ For Kierkegaard, conversion and, indeed, reconciliation become actual for a particular person by being appropriated to that person's existence in faith - the faith that is grounded in an interpersonal (person-to-person) relationship with God.

It is only through faith - or rather by the grace of God that upholds a person in faith that a person can actively participate in a relationship with the God-human, who is the object of faith. ${ }^{29}$ As Anti-Climacus writes further, with respect to a person's subjective perspective, 'if [Jesus] does not become the object of faith, he is not true God; and if he is not true God, then he does not save people either. ${ }^{30}$ The whole thrust of this passage is the insistence by Anti-Climacus that unless a person's relationship to God is grounded in the God-enabled faith relationship, then a person stands related to no more than her own independent (infinitely qualitative different) idea of God; and that is nothing more than a form of paganism.

\footnotetext{
${ }^{26}$ SKS 12, pp. 301-2 / Søren Kierkegaard, Without Authority, trans. Howard V. and Edna H. Hong (Princeton: Princeton University Press, 1997) (hereafter WA), p. 188.

${ }^{27}$ SKS 4, p. 264 / PF, p. 62.

${ }^{28}$ Barth, Church Dogmatics IV/3, p. 500.

${ }^{29}$ SKS 12, pp. 128-130, 136 / PC, pp. 121-4, 142-3. Anti-Climacus is not being subjectivist here but is merely affirming that, from the subject's perspective, the God-human exists only for faith.

${ }^{30}$ SKS 12, p. 141 / PC, pp. 137-8.
} 


\section{Distinguishing propositional and personal revelation}

Although, for Kierkegaard, the only point of contact between the divine subject and an individual human subject lies in the unifying person of Jesus Christ, he certainly did not deny that there is a real connection between the human mind and God's self-disclosure - a selfdisclosure that is accessed by propositional means. Clearly, human reason can recognise the truth of the Christian teaching that "there is a God who creates us, loves us and redeems us". ${ }^{31}$ Furthermore, Kierkegaard himself was committed to redescribing "what Christianity is" to Danish society, that is, articulating revelation in propositional ways. It was his conviction, indeed, that the redemption of human thought and reasoning was critical for the Christian life.

At the same time, Kierkegaard also recognised that a direct hearing of Christian teachings can only do so much for a person; mere hearing cannot, in and of itself, reconcile a person into the Christian faith. This is because the Christian faith involves considerably more than the possession of an informed belief that certain propositions about God are true. Rather, it involves participation in an intersubjective relationship with the God who is for us and with us in history: the 'God-man [who] is the truth. ${ }^{32}$ For Kierkegaard, it is by being given to share in this relationship, made possible through God's presence with humanity in Christ, that a person receives a renewed mind, in and through which she can know God in truth. The primary function of revelation, therefore, is to enable a person to know God in the context of relationship. As C. Stephen Evans notes, 'the primary object of revelation is God himself, not propositions about God, and the primary purpose of revelation is making possible a relationship with God. ${ }^{33}$ The important point here is that, for Kierkegaard, the living God who encounters us in and through the revelation of Jesus Christ must not and cannot be identified with "a truth" that can be directly apprehended by the human mind. Consequently, when George Pattison contends that, for Kierkegaard, 'the truth that is given in revelation is essentially and ontologically conformable to the structures of thinking, self-conscious human life', this fails to recognise two things: first, that the truth at the centre of Kierkegaard's Christian vision is the person of the wholly other God, and, second, that this God is only known in and through the redemption of our systems of thought from error. For both of these reasons, the reality of the absolutely different God is not, for Kierkegaard, 'essentially and

\footnotetext{
${ }^{31}$ We see this, for example, in Johannes Climacus' ability to envisage the possible truth of Christian teaching, whilst not being a Christian himself.

${ }^{32}$ SKS 25, p. 150, NB27:35 / JP 4, 4315.

${ }^{33}$ Evans, 'Faith and Reason' in The Oxford Handbook of Philosophy of Religion, ed. William Wainwright (New York: Oxford University Press, 2005), p. 327.
} 
ontologically conformable to the structures of thinking, self-conscious human life' ${ }^{34}$ The truth of God, Kierkegaard asserts with Augustine,

...is not subordinate to the human spirit (if it were, the human spirit then could not judge according to it but must exercise judgment over it), not coordinate (for then it would be inconstant like the human spirit), but the human spirit is subordinate to it - and this is to be truly free, when a person is the subordinate one. ${ }^{35}$

Pattison's suggestion that 'what happens in redemption is in essential conformity to the creaturely structures of human life' disregards Kierkegaard's emphasis that God's redemptive activity causes a person to 'lose continuity with himself' and '[become] a new creation., ${ }^{36}$ That is, he fails to take account of the fact that the grace of God confronts the creaturely way of life in an absolutely new way - in a way that is both creative and miraculous. For Kierkegaard, there is no prospective continuity and no possibility of any predetermination of the condition of God's engagement with the human. Any continuity can only be discerned retrospectively and in such a way that God's mediatory, transformative and redemptive activity is understood to be both foundational and also unanticipatable.

Pattison's concern is to stress that Kierkegaard resists 'a simple dualism' in which 'the redeemed self or the knowledge of God that is given in revelation is without essential relation to the natural self or to the general horizons of human knowledge. ${ }^{37}$ Pattison is right that Kierkegaard is disinterested in affirming a priori that all natural human cognition is absolutely different from redeemed human cognition. Yet Kierkegaard also recognises that the redeemed self is not in any sense an 'evolution' of the old natural self. ${ }^{38}$ Grace, for Kierkegaard, does not simply perfect our natural state; it redefines it. The redeemed self is delivered from her fallen natural existence into a wholly new way of life that is miraculously grounded in and sustained by the grace of God. When this occurs, the person no longer relates

\footnotetext{
${ }^{34}$ Pattison, Kierkegaard and the Theology of the Nineteenth Century, p. 89. We also find a similar position being advocated by M. Jamie Ferreira in 'The "Socratic secret" - The postscript to the Philosophical Crumbs' in Rick Furtak, ed., Concluding Unscientific Postscript: A Critical Guide (Cambridge: Cambridge University Press, 2010), pp. 6-24.

${ }^{35}$ SKS 24, pp. 282-3, NB23:157 / JP 4, 4877.

${ }^{36}$ SKS 7, p. 524 / CUP, p. 576.

${ }^{37}$ Pattison, Kierkegaard and the Theology of the Nineteenth Century, p. 89.

${ }^{38}$ As Climacus writes, 'Christianity will not be content to be an evolution within the total category of human nature; an engagement such as this is too little to offer to the god.' (SKS 7, p. 508 / CUP, p. 559).
} 
naturally to "God" as a conceptual postulate, idol or object of her imagination. Rather, she relates to God as a subject who delivers her from a radically erroneous orientation to reality in a way that entails a dying to her natural self - a "dying to the world" and "new birth". In this intersubjective event, she relates to God as a living subject who cannot be captured by the natural human mind: 'God cannot be an object for man, since God is subject' ${ }^{39}$ In short, God cannot be known by the alienated subject: God is neither a datum nor a factoid to be appropriated by the natural mind.

For this reason, faith in God is characterised by a belief that humbly recognises its inability to master or possess the eternal truth of who God is in the same way that a person might comprehend the truth of a proposition. For Kierkegaard, the only way for a person to relate to the truth of the divine subject is in and through a relationship with God's being for us in Christ. Anti-Climacus writes,

[Christ] knows that no human being can comprehend him, that the gnat that flies into the candlelight is not more certain of destruction than the person who wants to try to comprehend him or what is united in him: God and man. And yet he is the Savior, and for no human being is there salvation except through $\operatorname{him}^{40}$

Accordingly, when the Christian believes it is 'because he shall believe, rather than, as it is meaninglessly expressed, because he can comprehend. ${ }^{41}$ That is to say, when the Christian believes, she embraces a reality that, on the one hand, transforms her existence and understanding, and yet, on the other, cannot be directly appropriated by human reason.

To believe is to believe the divine and human together in Christ. To comprehend him [God] is to comprehend his life humanly. But to comprehend his life humanly is so far from being more than believing that it means to lose him if there is not believing in addition, since his life is what it is for faith, the divine-human. I can understand myself in believing... but comprehend faith or comprehend Christ, I cannot. On the contrary, I can understand that to be able

\footnotetext{
${ }^{39}$ SKS 20, p. 74, NB:88 / JP 2, 1349.

${ }^{40} S K S$ 12, p. $89 / P C$, p. 77.

${ }^{41} S K S$ 11, p. 65 / WA, p. 59 (emphasis original).
} 
to comprehend his life in every respect is the most absolute and also the most blasphemous misunderstanding. ${ }^{42}$

For Kierkegaard, a personal relationship with Christ (and the redemption of our reasoning that this brings) is not and cannot be generated by reflection on abstract statements about the truth of Christ. Rather, it involves a passionate response to the living Christ - a response that involves a 'redemption of reason' that, by the very nature of the case, could not possibly have been anticipated in advance. ${ }^{43}$ For Kierkegaard, divine truth is not possessed by the mind. Rather, the truth, as also our epistemic access to it, is identified with the person of Christ. He is both the truth and the way to the truth. ${ }^{44}$ '[W]e human beings, even if we are of the truth, are still alongside the truth; when we walk side by side with the man who is the Truth, when the Truth is the criterion, we are still like children alongside a giant; in the moment of decision we still remain - accomplices. ${ }^{45}$

The effect of this on Kierkegaard was to lead him to encourage an atmosphere of 'silence' and humility in the human sphere of knowing before God. ${ }^{46}$ But, as Dietrich Bonhoeffer would so stress, ${ }^{47}$ citing Kierkegaard, this is not a silence that allows the mind to chatter away to itself. ${ }^{48}$ It is the silence that recognises and hears Jesus Christ as the Word who exposes the error of our sinful minds and reconciles us into a faithful relationship with God. $^{49}$

\footnotetext{
${ }^{42}$ SKS 11, p. 70 / WA, p. 65 (emphasis original).

${ }^{43}$ Murray Rae, Kierkegaard's Vision of the Incarnation: By Faith Transformed (Oxford: Oxford University Press, 1997), p. 110.

${ }^{44} S K S$ 11, p. 90 / WA, p. 86; see also $S K S$ 12, pp. 203, 208 / PC, pp. 206, 210-1.

${ }^{45}$ SKS 10, p. 298 / Søren Kierkegaard, Christian Discourses, ed. \& trans. Howard V. and Edna H. Hong (Princeton: Princeton University Press, 1997) (hereafter $C D$ ), p. 278; cf. Jn. 18.37.

${ }^{46}$ SKS 12, p. 74 / Søren Kierkegaard, For Self-Examination, ed. \& trans. Howard V. and Edna H. Hong (Princeton: Princeton University Press, 1990) (hereafter FSE), p. 47; see also SKS 11, pp. 16-25 / WA, pp. 10-20.

${ }^{47}$ Dietrich Bonhoeffer, Christ the Center, trans. Edwin Robertson (New York: Harper \& Row, 1978), p. 27; see Dietrich Bonhoeffer, 'Christologievorlesung' in Gesammelte Schriften, vol. 3 (Theologie, Gemeinde, Vorlesungen, Briefe, Gesprache, 1927 bis 1944), ed. Eberhard Bethge (Munich: Kaiser, 1960), p. 167; Dietrich Bonhoeffer, Berlin, 1932-1933 (Bonhoeffer Works, Vol. 12,) ed. L. Rasmussen, trans. I. Best and D. Higgins, (Minneapolis: Fortress Press, 2009), pp. 300-1. (This more recent edition of Bonhoeffer's lectures on Christology does not show Bonhoeffer's reference to Kierkegaard because, as Christiane Tietz explains in her excellent chapter on Kierkegaard and Bonhoeffer, 'this new edition follows only one student's notes instead of being a compilation of several like the earlier edition was.' (Christiane Tietz, 'Dietrich Bonhoeffer: Standing "in the tradition of Christian Thinking" in Jon Stewart, ed., Kierkegaard's Influence on Theology - Tome I: German Protestant Theology (Farnham: Ashgate, 2012), p. 47 n.14).

${ }^{48}$ See $S K S$ 25, pp. 181-5, NB27:71 / JP, 6:6837; SKS 11, p. 78 / WA, p. 73.

${ }^{49}$ To use the terms that Bonhoeffer uses in the introduction to his lectures on Christology, Jesus Christ is the Logos who, with respect to our own logoi, is more precisely described as the counter-logos (Gegenlogos). (Bonhoeffer, Berlin, 1932-1933, p. 302).
} 


\section{Subjectivity as truth and untruth}

Few, if any other, statements have prompted so much misunderstanding of Kierkegaard as Climacus' statement that "subjectivity is truth". This has led theologians to view Kierkegaard as holding to an overly anthropocentric and existentialist vision of the Christian faith. Karl Barth, for example, in a letter to Helene Barth on $22^{\text {nd }}$ January 1944, writes, 'I had to understand Jesus Christ and bring him from the periphery of my thought to the centre. Because I cannot regard subjectivity as being truth, after a brief encounter I have had to move away from Kierkegaard again. ${ }^{, 50}$

Kierkegaard's/Climacus' statement that "subjectivity is truth" seeks to affirm that, because our personal perception of reality is the best we have to go by, we have no other option than to operate with our beliefs. ${ }^{51}$ Just because we cannot go beyond our own subjectivity in order to know with pure objectivity (that is, non-subjectively), does not commit us to a Cartesian strategy of hyperbolic doubt. For the Christian, this means embracing a faith in Christ in the recognition that her faith is enabled by the reality of God's grace, even though she cannot stand apart from her own subjective life and adopt an Archimedean point or "neutral space" from which to confirm that God is indeed working in her life, drawing her into a life of faith. If the Christian is not willing to trust her faith to the reality of God, then Christianity is no longer possible. ${ }^{52}$ The paradox here is the paradox that, to some extent, confronts all forms of realism: ${ }^{53}$ the Christian is called to believe that her faith in God is not simply a product of her own belief-forming imagination but is grounded in the reality of Christ: ${ }^{54}$ she is called to believe that she cannot believe without the one in whom she believes. Without Christ, she can only generate unchristian beliefs. ${ }^{55}$ And it is precisely this point that Barth affirms in 1928 when he writes: 'That my faith is accepted as true faith is

\footnotetext{
${ }^{50}$ Quoted in Busch, Karl Barth, p. 173. Notably, Barth later comments in 1962 that Kierkegaard's statement "subjectivity is truth" 'is at the very least open to misunderstanding'. (Karl Barth, Evangelical Theology (London: Weidenfeld and Nicolson, 1963), p. 82).

${ }^{51}$ See $S K S$ 22, p. 319, NB13:76 / KJN 6, p. 322.

${ }^{52}$ SKS 7, p. 307 / CUP, pp. 335-6 n.

${ }^{53}$ The realist is called to believe that the object of her perception has a real mind-independent existence that is not just a projection of her own imagination.

${ }^{54}$ Struggling with this paradox himself, Kierkegaard writes, 'If I consider my own personal life, am I thus a Christian or is my personal existence not a purely poet-existence, with even an element of something demonic... perhaps, because it might turn out that I didn't become a Christian after all.' (SKS 22, p. 127, NB11:204 / JP 6, 6431).

${ }^{55}$ In this way, Christians are confined to the same way of life as every other subjective human being. But what distinguishes them, as Ingolf Dalferth points out, 'is due not to what they do but to how they relate to what is done to them.' ('Becoming a Christian according to the Postscript: Kierkegaard's Christian Hermeneutics of existence' in N.J. Cappelørn and H. Deuser, ed., Kierkegaard Studies Yearbook 1999 (Berlin: Walter de Gruyter, 2005), p. 274).
} 
something again I can only believe - believe as I believe in the miracle of the divine mercy., 56

There is, however, a further point that needs to be made here. As Eberhard Jüngel points out, Kierkegaard's statement 'subjectivity is truth' requires to be interpreted dialectically with his further statement that 'subjectivity is untruth' ${ }^{57}$ For Kierkegaard, the suggestion that 'I live' the Christian life needs to be qualified retrospectively by the statement 'yet not I but Christ in me'. ${ }^{58}$ Again, the reality of God cannot be captured in a subjective human idea and so it is only in and through a relationship with the person of Jesus Christ "the way, and the truth, and the life" who lies beyond human subjectivity - that a person stands related to the truth of the Christian faith. This is not to suggest that Kierkegaard is contradicting himself. Without giving some kind of credence to the notion that subjectivity is truth, we are not able to believe passionately (or authentically) that God is enabling us to relate faithfully to him, in and through Christ; we are not able to be lifted beyond the suspicion that our faithful relationship with God is just another delusion of our mere subjectivity.

What we see here, in Kierkegaard's/Climacus' recognition that 'subjectivity is untruth', is an appreciation of precisely the point that Barth was making in his rejection of the statement 'subjectivity is truth'. For Kierkegaard, as we have seen, becoming a Christian does not merely involve the inward transformation of our knowing. It involves reconciliation into relationship with the truth: that is, into a relationship with the actuality of God who is present for us as one of us in history. This means that becoming a Christian is not grounded in a person's own immanent relationship to God per se but, rather, in God's active relationship to that person, mediated in and through the God-human.

That the human race is supposed to be in kinship with God is ancient paganism; but that an individual human being is God is Christianity, and this particular human being is the God-man. ${ }^{59}$

\footnotetext{
${ }^{56}$ Barth, Ethics, 103. Barth also writes, 'There is no visible sanctification of man; no sanctification which can be seen, proved or measured; none which does not have to be believed.' (Karl Barth, 'Church and Culture' in Theology and Church: Shorter Writings, 1920-1928, trans. Louise Pettibone Smith (London: SCM, 1926), p. $345)$.

${ }^{57}$ Eberhard Jüngel, 'Von der Dialektik zur Analogie: Die Schule Kierkegaards und der Einspruch Petersons' in Barth-Studien (Zürich: Benziger Verlag, 1982), pp. 168-9.

${ }_{58}^{58}$ See $S K S$ 10, pp. 264-5 / CD, p. 261; SKS 24, p. 186, NB22:152 / JP 4, 3956.

${ }^{59}$ SKS 12, p. 92 / PC, p. 82.
} 


\section{Kierkegaard's low pneumatology}

There is only one proof for the truth of [Christianity] - the inner proof, argumentum spiritus sancti. ${ }^{, 60}$

As we have just seen, while Kierkegaard insists that the Christian life is grounded in an outward relationship with God, ${ }^{61}$ he also insists that the eternal truth of God must engage a person inwardly or spiritually. In order to hold these two points together, one might have expected Kierkegaard to turn to the work of the Spirit. However, he rarely made this move. This rarity is arguably one of the greatest weaknesses in Kierkegaard's theology of conversion and reconciliation. With a more confident appreciation of the work of the promised Spirit, he might have been able to articulate more clearly the relationship between human immanence and the grace of God. For example, a higher profile pneumatology might have enabled him to articulate more clearly the way in which Christians relate subjectively to the objective presence of Jesus Christ and thereby to the objective reality of God - and in a manner which (contra Hegel's pantheism) maintains the two-sidedness of the relationship between God and humanity.

While Kierkegaard does not provide any extended discussion of the Spirit, he was not unaware of the importance of the work of the Spirit, as is particularly evident in his later works. $^{62}$ Speaking of conversion in Judge for Yourself, he observes that 'The Spirit brings faith, the faith - that is, faith in the strictest sense of the word, this gift of the Holy Spirit' ${ }^{63}$ In addition, he maintains that the Spirit must help us to know the Son, the Mediator, who

\footnotetext{
${ }^{60}$ SKS 22, p. 108, NB11:179 / KJN 6, p. 105.

${ }^{61}$ As Climacus maintains, Christian upbuilding is grounded in 'something outside the individual; the individual does not find the upbuilding by finding the relationship with God within himself but relates himself to something outside himself in order to find the upbuilding'. (SKS 7, p. 510 / CUP, pp. 560-1n.).

${ }^{62}$ See SKS 13, pp. 93-108 / Søren Kierkegaard, Judge for Yourself, ed. \& trans. Howard V. and Edna H. Hong (Princeton: Princeton University Press, 1990), pp. 71-87) (hereafter JFY); SKS 13, pp. 153-5/ FSE, pp. 95-8; and a string of later journal entries from 1850 (SKS 23, pp. 22-3, NB15:24 / JP 2, 1653; SKS 23, pp. 80-1, NB15:114 / JP 2, 1654; SKS 23, p. 414, NB20:40 / JP 2, 1656; SKS 23, p. 447, NB20:100 / JP 2, 1657; SKS 23, pp. 448-9, NB20:105 / JP 2, 1658; SKS 23, p. 463, NB20:133 / JP 4, 4462) and 1852 (SKS 25, pp. 46-7, NB26:40 / JP 2, 1661; SKS 25, p. 161, NB27:49 / JP 2, 1662; SKS 25, pp. 96-7, NB26:97 / JP 2, 1916; SKS 25, pp. 157-8, NB27:44 / JP 2, 1919; SKS 25, pp. 150-1, NB27:37 / JP 4, 4346; SKS 25, pp. 49-50, NB26:44 / JP 4, 4688; SKS 25, pp. 79-81, NB26:77/ JP 4, 4692; SKS 25, p.103, NB26:107 / JP 4, 4694; SKS 24, 519-20, NB25:107 / JP 4, 4939; SKS 24, 468-9, NB25:48 / JP 6, 6792; SKS 25, pp. 156-7, NB27:43 / JP 6, 6832). Also, Paul Martens' chapter, 'The Emergence of the Holy Spirit in Kierkegaard's Thought' offers a profoundly insightful analysis of Kierkegaard's thought on this topic (in International Kierkegaard Commentary on For Self Examination and Judge for Yourself, ed. Robert Perkins (Macon: Mercer University Press, 2002), pp. 199-222).

${ }_{63} S K S, 13$, p. 103 / FSE, p. 81 (Kierkegaard also talks about the Spirit's bringing of hope and love in this discourse).
} 
directs us to the Father: God 'becomes my Father in the Mediator by means of the Spirit. ${ }^{64}$ Such references to the Spirit hardly constitute a robust pneumatology. However, they do suggest that his theological convictions are compatible with, and may well be enhanced by, a more extensive treatment of the role of the Spirit.

Importantly, however, Kierkegaard was not without reason for referring to the Holy Spirit infrequently. The Hegelianism to which he was so resistant revolved around the concept of the divine spirit (Geist) and this conception of the divine spirit served to endorse a unity between God and human immanence. ${ }^{65} \mathrm{He}$ had also, and for related reasons, become nervous about giving too much attention to the Holy Spirit lest church-going "Christians" would be inclined to talk about the Spirit's work in their lives without attempting to lead the difficult Christian lives to which the New Testament calls them - lives of self-denial and renunciation. ${ }^{66}$ For him, those who kept turning to the Spirit in this way were "escapists" who expressed 'a pure and simple secular mentality' - an expression that is not inspired by the Holy Spirit. ${ }^{67}$ It was for this reason that he felt the need to provide a message that was more existentially concerned. By so doing, he was fully aware of how this might come across:

When I underscore the existential in the essentially Christian (alas, not nearly as strongly as the N.T.!) the cry goes up: This is exaggeration, this is law, not gospel. They say: You forget to talk about the Holy Spirit and his aid, for thereby what is heavy becomes light. ${ }^{68}$

Aware of how cheap references to the Holy Spirit had become, Kierkegaard responds to such criticism by saying, 'I have so much respect for the Holy Spirit that I have not dared speak of him because I understand that as soon as I begin doing so I must present the existential even more strongly. ${ }^{69}$ As he saw it, the children of Christendom had become so spoiled by talk of

\footnotetext{
${ }^{64}$ SKS 25, pp. 140-1, NB27:23 / JP 2, 1432. Importantly, Kierkegaard asserts here that 'it is not the Spirit who leads to the Son and the Son who leads to the Father; no, it is the Father who directs to the Son, the Son who directs to the Spirit, and not until then is it the Spirit who leads to the Son and the Son who leads to the Father.'

${ }^{65}$ See, for example, Hegel, Lectures on the Philosophy of Religion, vol. III, ed. P.C. Hodgson (Berkley: University of California Press, 1985), pp. 22, 170.

${ }^{66}$ Another contributing factor to the deficient pneumatology in Kierkegaard's thought is that Kierkegaard was influenced by some orthodox strands of Lutheranism in Denmark, which tended towards a more christocentric theology.

${ }^{67}$ SKS 24, p. 469, NB25:48 / JP 6, 6792.

${ }^{68} S K S$ 24, p. 469, NB25:48 / JP 6, 6792.

${ }^{69} S K S$ 24, p. 469, NB25:48 / JP 6, 6792; see also SKS 25, pp. 312-3, NB29:23 / JP 6, 6862.
} 
grace and the Holy Spirit that they had ceased to recognise that when God works in our lives we are drawn to a life of struggle in this secular world. ${ }^{70}$

The situation was such that people were praising God for their comfortable worldly lives - lives they believed were being made easier by the help of the Spirit. Consequently, Kierkegaard felt compelled to speak of the need for Christians to make a voluntary effort to follow Christ. For Kierkegaard, God works in our lives not by making difficult choices easy but by giving us the strength to make the difficult choices, the sacrifices, that we are called to make. He does this by sending the Holy Spirit to give us the "sobriety" to see the "drunkenness" of the secular mentality, and thereby to become inspired to adjust our lives according to Scripture's proclamation of what Christianity is. ${ }^{71}$

It is important to clarify here that Kierkegaard was not intent on making the prospect of becoming a Christian more difficult for everyone. In particular, he did not want to make the "common people" more anxious. ${ }^{72} \mathrm{He}$ did not want the struggling workers in society to perceive Christianity as yet another burden for their difficult lives. For those who were struggling, Kierkegaard (primarily) spoke a message of grace: Jesus Christ's 'reconciliation (Forsoning) expels, if possible, all anxiety from a person's soul. ${ }^{73}$ Becoming a Christian brings relief to those who are struggling with the ways of the world. But for those churchgoing "Christians" who are overly comfortable with the ways of the world, Kierkegaard (primarily) spoke a message of existential struggle - a message that, he believed, was strongly supported by the New Testament. For this group, it is much harder to become a Christian - harder than it is for the camel to go through the eye of a needle. Such people need to recognise their need to be reborn from above and to look to God and revelation in order to discover in truth what is involved in becoming a Christian - in consciously participating in God's kingdom in this world.

Why is it so difficult to become a Christian in this world? Because, for Kierkegaard, the faith and love that characterise the Christian life clash with the ways of this world, and we find this epitomised in this world's crucifixion of Jesus Christ, the God-human. In fact, the

\footnotetext{
${ }^{70}$ SKS 25, pp. 156-7, NB27:43 / JP 6, 6832.

${ }^{71} S K S$ 16, pp. 153-5/JFY, pp. 95-8.

${ }^{72} S K S$ 22, p. 360, NB14:28 / JP 6, 6531; see also $S K S$ 21, p. 286, NB10:57 / JP 1, 236; SKS 25, p. 154, NB22:92 / JP 1, 991; SKS 23, pp. 230-1, NB17:82 / JP 6, 6611, SKS 23, p. 316, NB18:90 / JP 6, 6628.

${ }^{73} S K S$ 16, p. 254 / JFY, p. 209 (emphasis original). Also, in a journal entry from 1850, Kierkegaard remarks that the difference between a pagan and a Christian is that 'When the pagan sins... he sinks into depression, broods introspectively over his guilt, and the sin perhaps gets more and more power over him, so that he despairingly sinks deeper and deeper. The Christian has a Savior; he takes refuge in "grace"; as with a child, his sin is transformed for him into a fatherly punishment intended to help him go forward.' (SKS 23, p. 83, NB15:118 / JP 4, 4032).
} 
Christian life is so radically at odds with the worldly life that, in a certain sense, it is almost impossible to become a Christian in this world - as is made evident when Kierkegaard goes so far as to claim "I am not a Christian". ${ }^{74}$ For Kierkegaard, almost no one can claim to become the 'infinitely high' Christian - the Christian according to the New Testament given the constraints of existence in this fallen world. ${ }^{75}$ However, when we realise the hopelessness of our individual pursuits, Kierkegaard asserts that we must not become overwhelmed with guilt, anxiety and despair. Instead, with Luther, we turn with our anguished consciences to trust that it is only by grace that we are saved. ${ }^{76}$ For Kierkegaard, as Jørgen Bukdahl notes, '[t]he only salvation is, first of all, honesty and the admission that one is humbled, crushed under the weight of this high ideal. Thereafter, the only things remaining are grace and God's mercy. ${ }^{77}$ It is with a hope that looks to God's grace and mercy (and, thus, away from ourselves) that we become Christian; and, for Kierkegaard, this hope is brought to us by the Holy Spirit - a hope that is not 'natural hope' but 'hope in the strictest Christian sense' ${ }^{78}$ It is by trusting in this hope that we can call ourselves Christian.

With a sword hanging over my head, I am ordered to say whether or not I am a Christian. My answer would be: I trust to God that I am a Christian; I believe that out of grace he will accept me as a Christian... The question of whether I am a Christian (and thus for every individual, whether he is a Christian) is entirely a God-relationship. ${ }^{79}$

\section{Conclusion}

It is not difficult to look to some areas in Kierkegaard's works and align him with a wide range of accounts that place human existence at the centre of the Christian faith. However, it is a profound mistake to caricature him as holding to a primarily existentialist vision of the Christian faith. For Kierkegaard, a person is drawn into relationship with God in and through the person of Jesus Christ and by the Spirit. By standing before God and being given to

\footnotetext{
${ }^{74}$ SKS 13, pp. 403-7 / Søren Kierkegaard, The Moment and Late Writings, ed. \& trans. Howard V. and Edna H. Hong (Princeton: Princeton University Press, 1998) (hereafter $M$ ), pp. 340-3.

${ }^{75} S K S$ 13, p. 411 / M, pp. 346-7.

${ }^{76}$ SKS 20, 69, NB:79 / JP, 3:2461.

77 Jørgen Bukdahl, Søren Kierkegaard and the Common Man, trans. Bruce H. Kirmmse (Grand Rapids: Eerdmans, 2001), p. 126.

${ }^{78}$ SKS 13, p. 104 / FSE, pp. 82-3.

${ }^{79}$ SKS 16, p. 111, BN / PV, p. 135; see also Keith Lane, 'The Uncertainty of the Confessing Christian' in Kierkegaard and the Concept of Religious Authorship (Tübingen: Mohr Siebeck, 2010), pp. 139-45.
} 
experience God's presence in Jesus Christ through the reconciliation of her mind, a person's existence becomes caught up with the grace of God. In and through this active encounter with God, her passions find new direction and her existence finds new substance. What enables persons to participate in a faithful relationship with the God who is infinitely qualitatively different is nothing less than God's unity with the individual human being in Christ.

With this understanding, Kierkegaard developed a theology that challenged the overpowering belief that we are able to relate to God without the person of God, or that God can be comprehended within the realm of finite human understanding and language - a move that, as history has since confirmed, all too easily enables "God" to become a plaything to be employed for society's own agendas. For Kierkegaard, it is only when a person is drawn into an interpersonal relationship with Jesus Christ that she is drawn into the embrace of reconciliation. Furthermore, it is for the purposes of full participation in this relationship that a person is transformed by the grace of God into an active life of Christian discipleship. ${ }^{80}$

\footnotetext{
${ }^{80}$ I would like to thank Murray Rae and Christopher Holmes for their helpful feedback on an earlier version of this paper.
} 